\title{
A Descriptive Study of Community Health Education Jobs in the U.S.A., May - December 1998
}

\author{
Larry $\mathrm{Wu}$
}

\author{
Angion Biomedica, Inc.
}

\begin{abstract}
The purpose of this study was to explore the community health education jobs in the USA and to provide relevant workforce information to community health education professionals and students. Two hundred fifty community health education announcements out of 908 were randomly selected from the Heath Education Professional Resources (HEPR) Job Bank for the periods May to December of 1998. Job information such as job searching methods, working environments, job qualifications, job descriptions, salaries, and benefits of community health education professionals were characterized. RESULTS: October had the highest number of job announcements during eighth-month period. There were more job announcements from the Northeast and West. Many of the job announcements were obtained through CareerPath ${ }^{\circledR}$ and America's Job Bank ${ }^{\circledR}$. There were at least 137 different job titles. The majority of institutions hiring health educators were either non-profit or government. About two-thirds were public organizations. The majority of the positions (86\%) required applicants to have either a baccalaureate or master's degree. There were diverse job qualifications. College majors other than health education or community health were acceptable. Work experience in descending order were: program planning and evaluation, program management, working with diverse populations, community organization and coordination, and working with multicultural populations in descending order. One to five years of working experience was required for the job positions. Target population and target issues were diverse. Almost half of the health educators served general health issues in their community. Computer skills, particularly word processing and Internet skills, were required. The capacity for working independently and self-motivation were significant factors in the hiring for most of the employers. Communication skills were required in $80 \%$ of the job announcements. Other required skills included program assessment, planning, implementation, evaluation, and teaching. For full-time employees, the median salary was $\$ 36,000$. Other employee compensation information is also reported.
\end{abstract}

(c) 2003 Californian Journal of Health Promotion. All rights reserved.

Keywords: health education jobs, workforce, professional issues, employer

\section{Introduction}

\section{Profession}

Health Education As An Evolving

The health education profession has been evolving over the past 20 years with the development of defined professional responsibilities and competencies (NCHEC, 1996, 1999), individual and programmatic credentialing programs (SABPAC, 1990; Cleary, 1995; NCHEC, 1996), defined theories and models to guide professional practice (Green \& Kreuter, 1991; Bartholomew, Parcel,
Kok, Gottlieb, 2001), a professional code of ethics (Anonymous, 2000; Capwell, Smith, Shirreffs, and Losen, 2000), and a governmental mandate for the role of health education to improve the health of all Americans (USPHS, 1991). "Public health educator" was recently listed with the U. S. Department of Labor Occupational Classification System Manual (USDOL, 2000) and job related statistics may be generated within the next few years. Despite such professional progress, almost no research has been conducted on the professional 
workforce to assess typical job characteristics. Without such information, professional preparation programs are unable to attract and educate students about career opportunities, professional health educators cannot make informed career decisions, and professional associations cannot coordinate fact-based programs to educate employers about what is health education and what are the responsibilities and competencies of the professional health educator. What are the job titles, work settings, job qualifications, job descriptions, and salaries of health educators? In what part of the USA are jobs being offered?

The purpose of this study was to explore the characteristics of community health education jobs in the USA found on the Internet from May-December 1998.

\section{Statement of the Problem}

What are the job characteristics of community health education jobs in the USA from MayDecember 1998?

\section{Research Questions}

This study focused on the following questions regarding community health education jobs in the USA from May-December 1998.

1. Where are community health education job announcements in the USA found on the Internet from May-December 1998?

2. What is the seasonal distribution of community health education jobs in the USA from May-December 1998?

3. What is the geographic distribution of community health education jobs in the USA from May-December 1998?

4. What are the typical job titles for community health education jobs in the USA from May-December 1998?

5. In what types of institutions are community health education jobs offered in the USA from May-December 1998 ?

6. What are the professional qualifications for community health education jobs in the USA from May-December 1998?
7. What are the job descriptions of community health education jobs in the USA from May-December 1998?

8. What are the special skills being requested for community health education jobs in the USA from MayDecember 1998?

9. What compensation packages for community health education jobs in the USA from May-December 1998?

\section{Definition}

Community Health Educator refers to a professional who applies "a variety of methods that results in the education and mobilization of community members in actions for resolving health issues and problems which affect the community. These methods include, but are not limited to, group process, mass media, communication, community organization, organization development, strategic planning, skills training, legislation, policy making and advocacy (JCHET, 1991, p. 105).”

\section{Delimitations}

This study was delimited to a randomized sample of community health education job announcements obtained through Health Education Professional Resources Job Bank (Taub \& Tomita, 2000) in the USA from MayDecember 1998. The study is be limited only to community health education job announcements.

\section{Limitations}

The findings from this study may not be generalized to all community health education jobs in the USA from May-December 1998, because only one source, the HEPR Job Bank (Taub \& Tomita, 2000), was used as a source of data. The methods used by the HEPR Job Bank Staff to collect job announcements are primarily conducted through online resources, and is not comprehensive.

\section{Significance of Study}

There are three major reasons why this study was important to conduct. First, there has been no national studies to assess typical community health education jobs in the USA. Such workforce studies are essential to evaluating the health education profession and the formation of 
policies and agendas that affect the profession. How can professional associations in cooperation with governmental agencies and other professional bodies plan for workforce needs in the 21st Century without having basic information about community health education jobs? It is simply not possible, and such planning will be based upon opinions and hearsay rather than on facts.

Second, students and community health educators need job information to make informed decisions about their career options. Professional preparation programs may be tailored to address career issues such as work settings, salaries, clinical versus administrative ladders, and other information needed for graduating students to make informed choices about their careers. Also, faculty in these programs may address competencies required of entry-level community health educators by employers and may job attainment may be used as an outcome measure for programmatic evaluation.

Third, this study may help community health education administrators and employers examine how their organizations compare with other places of employment, and clarify the professional competencies required for community health education jobs.

\section{Literature Review}

An extensive literature review yielded a paucity of information regarding community health education jobs. However, a literature is presented in this chapter in the order of Health Education Professional Resources Job Bank (where data for this study was obtained), how community health education job were obtained from the Internet, and related information, and community health education job qualifications, descriptions, and employee compensation. The reason for inclusion of job search strategies using the Internet is because its use in the profession is relatively new and unknown, and it illustrates how computer technology may be used for professional purposes.

Other health education job studies have been reported, however, they will not be discussed because they are beyond the scope of this study on community health education jobs (Crase \& Hamrick, 1990; Moore, Pealer, Weiler, \& Seabert, 1999).

\section{Health Education Professional Resources Job Bank}

The World Wide Web (web) has made it possible to search for community health education jobs online. One web site in particular is Health Education Professional Resources (HEPR) (Taub \& Tomita, 2000). HEPR is one of the largest professional health education web site in the world, housing among other resources, the HEPR Job Bank. HEPR began in 1996 as a professional resource to health educators (Taub \& Tomita, 2000; Tomita, 2000). This resource would be web-based, and would provide information about the health education profession. One of the most popular and frequently used feature of HEPR is the Job Bank. HEPR receives over 1 millions hits per year, almost three-fourths of which for the Job Bank (Tomita, 2000). The HEPR Job Bank contains listings of health education job announcements categorized into: College/ University: Academic Faculty, College/ University: Student Health Services, Community, Internships/ Grad. Assistantships, K-12 Health Teachers, Outside USA. Job announcements in each of these categories may either be browsed or searched by the user. The job announcements of interest to this study are the community health educator positions.

\section{Online Community Health Education Job Search Strategies}

Tomita \& Taub (1999) explored various methods to find health education job announcements on Internet at the time. They listed web sites relating to health education jobs, as well as common job search engines for health educators. Among the more productive job search engines at the time for community health educators were CareerPath (CareerPath, 2000), America's Job Bank (AJB, 2000), MonsterBoard (MonsterBoard, 2000), and Public Health Employment Connection (Emory University, 2000). They also provided health education job seekers valuable advice on how and where to find their ideal positions: searching health 
education job-specific web sites is the easiest and most direct method to find a job in the area. But using more than one method will increase the chances of finding job possibilities. Those who master the electronic world of the Internet will enhance their success in finding their ideal jobs. The methods described in Tomita \& Taub (1999) were used to collect job announcements for the HEPR Job Bank (Taub \& Tomita, 2000) by the HEPR staff. These job announcements were used in this study.

\section{Community Health Educator Job Qualifications}

It is generally accepted in health education that an individual who possesses a baccalaureate degree in a health education major meets the minimum educational requirement of the profession. In addition to a college degree and appropriate major, certification as a Certified Health Education Specialist (CHES)(NCHEC, 1996) is optional, although the creation of the certification was meant to further the development of the profession by creating standards of practice, and viewed as an essential job qualification (Cleary, 1995; Girvan \& Kearns, 1993; Hager, 1997; Mail, 1994; Ricketts, 2000). There still exists, however, controversy over the utility of the CHES certification in the workplace (Butler, 1997).

Although the community health educator job qualifications are clearly defined by the profession, there is the lack of understanding by employers that such standards exist (Bajracharya, 1999; Sondag, Taylor, \& Goldsmith, 1993). Sondag et al. (1993) in a study of community and worksite settings, found that the majority of health education responsibilities were being performed by individuals other than health educators. Likewise, Bajracharya (1999) found only 25\% of responsibilities in rural health department were being performed by health educators.

Pickett \& Pickett (1995) provided an introduction into careers as a public health educator, in which they described the qualifications, position responsibility, job prospect and salary range for health educators (Pickett \& Pickett, 1995, p. 82).

\section{Community Health Educator Job Description}

Cottrell, Girvan, \& McKenzie (1999) discussed the job descriptions of health educators working in community, worksite, and health care settings. Aside from job expectations of assessment, planning, implementation, and evaluation of health education programs, community health educators are expected to be able to work with diverse groups of people, and engage in other activities such as "fund-raising, coalition building, committee work, budgeting, general administration, public speaking, volunteer recruitment, grant writing, and media advocacy (p. 170).

Four survey studies of community health education employers and/or college faculty reveals a wide variety of skills and personal attributes required of community health educators in their jobs (Bajracharya, 1999; Lindsay, Hanks, Neiger, \& Barnes, 2000; Timmreck and Cole, 1989; Sondag et al., 1993). These studies span the last decade and are reveal the level of expectations by employers of community health educators.

Timmreck and Cole (1989) emphasized health service administration skills, which are usually overlooked in community health education and health promotion. These skills include program assessment, planning, implementation, and evaluation. In addition, community health educators are expected to coordinate, analyze, and organize. Other skills required were accounting, budgeting, personnel managing, computing and marketing. In addition to the tasks of helping people change their lifestyles, other practical activities such as identifying objectives, planning programs and developing budgets are also common for health educators in their profession. Most health service agencies and private businesses hiring graduates from health education or health promotion fields expect them to possess certain health administration skills or at least to be trained in these areas (Bonaguro, 1983; Parlettee, 1981; Squyres, 1982). 
Sondag et al. (1993) examined employer perceptions of the importance of entry-level health education skills. The results showed that the respondents generally felt that certain skills were essential even at entry level. The skills they identified were: coordination, program assessment, program planning, program implementation, program evaluation, communication, as well as the capability of acting as an resource person. Among these skills, they found that in communication, program assessment, and acting as an resource person were the most important for the employers. They also found that there were differences in employer's perception depending on the types of organization. For instance, the need for communication skills and the capability of acting as an information resource are more important for employers in community settings than for those of worksite settings.

In another study, Bajracharya (1999) listed seven health education skills perceived to be important for rural community health employers. The skills were ranked from the most to the least important: communication and health education, assessing community needs, planning programs, implementing programs, coordinating programs, acting as a resource person, and evaluating programs.

Lindsay et al. (2000) surveyed health department employers and faculty from health education professional preparation programs. They found the most important skills for graduating students entering the workforce to possess included writing, public speaking, and presentation skills. CHES certification was not viewed as being optional.

Responsibilities and skills required of community health educators are consistent with that generally expected (Anspaugh, Dignan, \& Anspaugh, 2000; Cottrell, Girvan, McKenzie, 1999; Doyle \& Ward, 2001; Steuart \& Kark, 1993).

\section{Working With Diverse and Multicultural Populations}

Health educators often work with diverse and multicultural populations. The target population of the community health educator may include varying ages, races and ethnicities, religions, and other groups. Development of "cultural competence," or the ability of the community health educator to work with a groups of individuals from another culture successfully, is essential to the success of public health interventions (Buchanan, 1998). The necessity of cultural competence is consistent with other studies (Bayer, 1994; Green, 1982; Orlandi, 1992; Stoy, 2000).

\section{Research Methods}

The purpose of this study was to examine community health education job information in the USA during May-December 1998. The process consisted of four stages: 1) community health education job announcements from May to December 1998 were obtained from the Health Education Professional Resources Job Bank; 2) 28 job information categories were extracted from the job announcements; 3) an employer questionnaire was developed to obtain missing information from the job announcements; 4) the data were processed and analyzed using SPSS ${ }^{\circledR}$. This study was approved by the Brooklyn College Institutional Review Board in Spring 2000. The NIH Office of Human Subjects Research computer-based training course on the Protection of Human Research Subjects was completed by the principal investigator.

\section{Health Education Professional Resources (HEPR) Job Bank}

Nine hundred and eight community health education job announcements for the period May to December 1998 were obtained from Professor Mark Tomita, Co-Administrator of the Health Education Professional Resources (HEPR) Job Bank (Taub \& Tomita, 2000). HEPR Job Bank jobs are pre-sorted for browsing in six categories according to the areas of professional practice: College/University: Academic Faculty, College/University: Student Health Services, Community, Internships/ Graduate Assistantships, K-12 Health Teachers, Outside USA. Only those job announcements from the Community job category were obtained from Professor Tomita and used in this study. Data were not collected by the principal 
investigator of this study, rather, obtained existing data. The data received from the HEPR Job Bank were publicly available on the Internet in 1998.

\section{Data Collection Procedures Used by the HEPR Job Bank Staff}

A variety of methods were used by the HEPR staff to find community health education job announcements posted on the Internet (see Tomita \& Taub, 1999, for search methods). These methods produced health education job announcements from web sites (health education job web sites, organizational and governmental job web sites, job search engines, and web-based newspaper classified listings), professional electronic mailing lists, USENET newsgroups, and bulletin board services. The majority of community health education job announcements were collected by the HEPR staff from the following web sites: America's Job Bank (AJB, 2000), CareerPath (CareerPath, 2000), MonsterBoard (MonsterBoard, 2000), CareerWeb (CareerWeb, 2000), North Carolina Employment Security Commission (NCESC, 2000), Chronicle of Higher Education (Chronicle, 2000), and Public Health Employment Connection (Emory University, 2000). Other sources of job announcements included direct submissions by employers directly to HEPR, Health Education Directory (HEDIR)(HEDIR, 2000), and Health Promotion Recruiters International (HPRI)(HPRI, 1998).

The keywords used to find community health education jobs by the HEPR staff were (Tomita \& Taub, 1999): health education, health promotion, health educator, community health, public health, outreach worker, health teacher, program director, program coordinator, program manager, wellness, and lifestyle. Community health education job announcements that were listed at the HEPR job bank had to satisfy at least one of the following criteria to be considered a community health education job:

1) the job title contained health educationrelated terms (e.g., health educator, health education coordinator, health promotion director);
2) the words "health education" or "health promotion" emerged in the majors needed for the job position;

3) the job qualification skills were specific to health education (e.g., program assessment, planning, implementation, evaluation, research, consulting, and administration);

4) the responsibilities and descriptions of the job position contained the tasks of health education or health promotion;

5 ) in the description of the announcement, the term of "health education" or "health promotion" emerged, or the job tasks relating to health educator were described; and

6) the job position required the applicant to possess or be eligible to become a Certified Health Education Specialist (CHES) (NCHEC, 2000).

\section{Random Selection of Community Health Education Job Announcements}

Nine hundred eight community health education job announcements were obtained from the HEPR Job Bank (Taub \& Tomita, 2000). Every fourth announcement was selected until a total of 250 was reached. The number of announcements required in this study was based on an anticipated mild response rate because there were no prior studies for comparison to estimate sample size. A response rate above $50 \%$ would still allow for regression analysis with a moderate effect at alpha $=.05$ and 0.80 power for multiple regression analyses (Cohen, 1988) if it were indicated.

\section{Procedures Used to Extract Job Information Categories \\ Coding Information: A coding scheme} Weitzman (1999) was used to categorize related concepts. This scheme involved the use of tags to label conceptual categories. Blocks of text from the community health education job announcements were assigned codes. A combination of repeated coding of conceptual categories refinement and familiarity with the community health education job market led to the development of a set of job information categories that would be pursued for analyses. 
Constructing the Database: Microsoft Access ${ }^{\circledR}$ was chosen for use in this study to construct a database because it is user-friendly, has extensive database management features, and it is compatible with Microsoft Word ${ }^{\circledR}$ and SPSS ${ }^{\circledR}$ for data translation.

Variable fields and codes were developed where information such as employer name and address were entered into the database. Missing information was represented by the code “ -99 ”. The database was queried repeatedly to determine what missing information had to be obtained either from the Internet or from the community health education employers through a paper-and-pencil survey.

\section{Obtaining Missing Information from the World Wide Web}

Many of the 250 community health education job announcements contained missing information. The World Wide Web (web) was used to access publicly available information about the community health education employers. The use of the web prevented unnecessary surveying of the employers, in other words, if the information could be obtained through the web, there was no reason to contact the employers. The web offered a method to obtain information such as complete name of the institution, contact information such as mailing address and phone number, and other information. Examples of other information that could be obtained through the web were profit or non-profit status, public, private or government agency, and employee compensation.

To find the employer web sites, search engines were used. These search engines included SearchaLot (SearchaLot, 2000), Yahoo! (Yahoo!, 2000), DirectHit (DirectHit, 2000), HotBot (HotBot, 2000), Netscape (Netscape, 2000), and AltaVista (AltaVista, 2000). Keywords of institution's names were used to find their respective web sites. Most large institutions possessed their own web sites, where addresses, human resource/personnel department contact persons and their titles, and other information could obtained.
There were many community health education job announcements that contained only addresses, contact persons with phone numbers, or other information without institution names. To find the missing names and other information, search engines such as AnyWho (AnyWho, 2000), BigBook (BigBook, 2000), and SearchBug (SearchBug, 2000) were used. Keywords containing the available addresses, phone numbers (reverse lookup) and contact person names were queried. In some cases, contact person names and their job titles, complete mailing addresses could not be obtained through the web. In these cases, the employers were contacted by e-mail or fax to request this information. A brief explanation was given. There was a $100 \%$ response rate to these specific requests.

\section{Community Health Education Employer Questionnaire}

The Total Design Method (TDM) (Dillman, 2000) was used as a guide to design the employer questionnaire and to implement the paper-and-pencil, postal mail research methods. The goal of surveying the employers were to obtain the missing information from community health education job announcements.

Employer Questionnaire: The Employer Questionnaire (see Appendix A) was developed using the Total Design Method (Dillman, 2000). The goal was to design a questionnaire that was easy to understand and easy to complete in the shortest amount of time.

The Questionnaire consisted of four sections with a total of 17 questions (see Appendix A). Each question included up to 17 response items. All of the questions were based on the literature review and the queries from the database. The four sections were respectively, institution information, job qualifications, job description, and employee compensation.

In the institution information section, three kinds of information were described: Whether or not the institution was public or private. Was it for profit, non-profit or government? Was it any one of the following kinds of institutions: community health center, clinical institution, 
government health department, research institution, education institution, nonprofit health-related agency, insurance company, consulting organization, health management organization, etc. The information was important because different institutions had different positions for the community health educators and they provided different benefits to their employee.

In the job qualifications section, information such as what college degree and majors were required were included. If a health education degree was required, what specialty area? Other questions included what degrees and majors were acceptable other than health education? The other information asked related to the specific experiences and years of these experiences needed for the job position.

In the job description section, information about the target population of the community health educator (e.g., children, seniors, students, families, etc.), target health issues (e.g., asthma, hypertension, substance abuse, etc.), and travel requirements for the job. Also, what special skills were being sought for the position (e.g., administration, budget, grant writing, program design, etc.), computer skills, and even the personalities suitable to the job.

The last section of the Questionnaire was the employee compensation section. Information about annual salary for a full-time position or hourly wages for a part time position, and any other benefits. Other benefits refer to various insurances provided to the employee and their families, paid leaves, paid vacation, pension, bonus, paid training, tuition reimbursement, merit pay, and so on.

The employers were informed about the purpose and importance of the study, requirements and benefits of participation, how the employers were selected for the study, assurance of confidentiality, and contact information of the principal investigator and supervising faculty member. Participation in the study was considered an implied informed consent. A signed informed consent form was not used in this study because the information being collected was publicly available.

\section{Procedure}

Postal mailing and follow-up of questionnaires packets were conducted according to Dillman (2000). To limit the amount of time required for the employer to provide the missing information needed for that specific job announcement, only those questions on the Questionnaire were highlighted with a yellow marker. The employers were instructed to completed on the highlighted questions.

\section{Data Analyses}

The 250 community health education job announcements randomly selected from the HEPR Job Bank (Taub \& Tomita, 2000) database contained four variables with complete information. All other variables under investigation in this study to characterize community health education jobs had missing information for which the Employer Questionnaires were mailed.

Data from the completed questionnaires were entered into MS Access ${ }^{\circledR}$ and later imported into SPSS ${ }^{\circledR}$ for analyses. The records in the database were marked when the corresponding questionnaires were received to avoid duplication of data. If two questionnaires received had the same job announcement identification number, the second data set was eliminated. Six instances of this situation occurred. Primary statistical analytic techniques involved descriptive rather than inferential statistics. Descriptive statistical analyses (e.g., frequencies, percentages, means, standard deviations) were performed on all variables under investigation in this study.

\section{Results}

The results of this study are presented according to the order of the nine research questions proposed earlier. It must be noted that before the Employer Questionnaires were mailed to obtain missing information, there were some variables that contained no missing information among the 250 community health education job announcements (e.g., seasonal and geographic distribution of jobs and where jobs were found 
on the Internet). All other remaining variables were examine with 115 completed cases. Thus, some results are based upon an $\mathrm{N}$ of 115 while others on 250.

\section{Questionnaire Response Rate}

One hundred forty five out of 250 questionnaires mailed (58\%) were received. However, only 115 complete questionnaires were valid, with a response rate of $46 \%$. Invalid questionnaires contained incorrect addresses, incomplete answers, or redundant replies from the same employers.

\section{Where Community Health Education Job Announcements are Found on the Internet}

Research Question \#1, "Where are community health education job announcements in the USA found on the Internet from May-December 1998?," was answered through the analysis of job announcement sources. All of the community health education job announcements were obtained from the HEPR Job Bank. The results show that almost half $(47.6 \%)$ of the job announcements were obtained through CareerPath (CareerPath, 2000), a database of online classified jobs from nearly 100 newspapers from across the USA. About onefifth (20.4\%) of job announcements were from America's Job Bank (AJB, 2000), an online cooperative venture between the US Department of Labor and US state Departments of Labor, Commerce, or Employment Security. The other sources of community health education job announcements included MonsterBoard (8.4\%), federal government (6.8\%), CareerMosaic (2.8\%), Health Promotion Recruiters International (2.4\%), Public Health Employment (2\%), North Carolina Employment Security Commission (1.2\%), and other sources $(<1 \%$ each).

\section{Seasonal Distribution of Community Health Education Jobs}

Research Question \#2, "What is the seasonal distribution of community health education jobs in the USA from May-December 1998?”, was answered by examining the number of announcements per month $(\mathrm{N}=250)$. October exhibited the highest frequency of jobs in community health education (16.8\%). Relatively high percentage of job announcements were found in May (13.6\%), August (12.8\%), September (15.2\%), and November (13.6\%). Relatively low percent of job announcements were found in December (9.6\%), July (8.4\%), and June (7.6\%), and $2.4 \%$ of job announcement dates were not identified. The trend observed from June to October is one of a tendency toward gradual increase. From October to December, it exhibited a gradual decrease.

\section{Geographic Distribution of Community Health Education Jobs}

Research Question \#3, "What is the geographic distribution of community health education jobs in the USA from May-December 1998?”, was answered through analysis of the job location by USA region. The geographic distribution of community health education jobs revealed Northeast (30.8\%) and West (30.4\%) had the highest percent of available positions, followed by Middle West (12.8\%), Southeast (18\%), and Southwest (8\%).

\section{Job Titles}

Research Question \#4, "What are the typical job titles for community health education jobs in the USA from May-December 1998?”, was answered by listing all job titles and determining the most frequently occurring. There was a total of 143 job titles for community health education jobs ( $\mathrm{N}=250)$ (see Appendix B for complete list). The job title of Health Educator had the highest percent (25.5\%), followed by Health Education Specialist (2.8\%), and Health Educator II and Public Health Educator (tied at 2.4\%). Interestingly, the job titles Community Health Education Coordinator, Community Health Educator, and Community Health Educator II each occurred in only $1-2 \%$ of the cases. The majority of job titles (45.6\%) were repeated only once.

The structures of community health education jobs titles vary, and may be categories into four categories according to: target health issue (e.g., AIDS Educator, Diabetes Project Coordinator, and Lifestyle Educator), job qualification (e.g., Bilingual Family Educator, Certified Childbirth 
Educator, etc.), professional hierarchy (e.g., Health Education Associate, Health Educator I, Health Educator II, Health Educator III, Health Education Specialist, Senior Health Educator), administrative hierarchy (e.g., Assistant Wellness Director, Disease Control Program Administrator, and Health Care Program Manager, Dean of Health Careers and Wellness), area of professional responsibility (e.g., Community Education Coordinator, Public Health Advisor, Wellness Education Consultant, etc.).

\section{Work Environment Characteristics}

Research Question \#5, "In what types of institutions are community health education jobs offered in the USA from May-December 1998?", were answered by examining the number of institutions that were either $(\mathrm{N}=115)$ : 1) for-profit, non-profit, or government, and 2) specific work setting.

More than half of the community health education jobs were offered in institutions that were non-profit ( $\mathrm{N}=106,56.5 \%)$ and a little over a third of in government $(\mathrm{N}=41,35.7 \%)$. Only a small portion of jobs were offered in institutions that were for-profit $(\mathrm{N}=9,7.8 \%)$.

The community health education jobs were then examined for their specific work setting. There were nine specific working settings identified. Most job positions ( $\mathrm{N}=65,56.5 \%)$ ) were in a government agency $(\mathrm{N}=33,28.7 \%)$ and nonprofit health-related organizations $(\mathrm{N}=32$, $27.8 \%$ ). Jobs in the remaining work settings occurred in less than $10 \%$ of the cases: Community health centers (9\%), health management organizations (9\%), medical treatment facilities (e.g., hospitals, clinics, and nursing homes) (8\%), and educational institutions (e.g., schools, colleges and universities) (8\%), health research institution (5.2\%), health consulting organizations (4.3\%), other $(3.5 \%)$, and insurance company $(0.9 \%)$. The work settings with the lowest percent of cases in for-profit institutions.

\section{Job Qualifications}

Research Question \#6, "What are the professional qualifications for community health education jobs in the USA from May-December 1998?”, was answered by examining individual qualifications: college degree, licensure/ certification, college major, type of work experience, and years of work experience. Each of these job qualifications will be discussed below separately.

College Degree: Forty eight percent of the jobs required the baccalaureate degree $(\mathrm{N}=48)$, $25.2 \%$ a master's degree $(\mathrm{N}=29), 19.1 \%$ required a baccalaureate degree but preferred the master degree ( $\mathrm{N}=22), 6.1 \%$ a master's degree, but doctorate preferred, and $4 \%$ required a $\mathrm{PhD}$ degree $(\mathrm{N}=115)$. A majority $(95.7 \%)$ of jobs required at least a baccalaureate degree. Only $4.3 \%$ of jobs either required no college degree or an AAS degree was required. Half of the jobs required or preferred a master's degree.

Licensure/Certification: Certified Health Education Specialist (CHES) certification was either required or preferred in only $8.4 \%$ of jobs out of 115 cases. Seven jobs (2.8\%) required $\mathrm{RN}$ licenses, although as will be discussed below, Nursing was among the list of alternative college majors acceptable for community health education jobs announced.

College Major: There were four college major requested among the job qualifications $(\mathrm{N}=115)$ : health education (37.4\%), public/community health (20\%), either health education or public/community health (31.3\%), and no major required (11.3\%). The results indicate $88.7 \%$ of jobs required a health education and/or public/community health major.

In addition to the college majors above, employers were also asked if there were alternative majors acceptable for the job positions. Only $6.1 \%$ of respondents did not accept alternative majors to other than health education or public/community health. There were at least 19 types of majors acceptable as a community health education job qualification other than those mentioned above.

Non-health education majors are listed below in Table 1. A "Health-Related Major" was acceptable in $60.9 \%$ of the job announcements 
$(\mathrm{N}=70)$. The four most frequently cited alternative college majors were Education
(36.5\%), Nursing (35.7\%), Social Sciences (30.4\%), and Human Services (25.2\%).

Table 1

Percentage Of Alternative Majors Acceptable For The Jobs

\begin{tabular}{|l|c|c|}
\hline \multicolumn{1}{|c|}{ Alternative Majors } & Frequency & Percent \\
\hline Health-Related Majors & 70 & 60.9 \\
\hline Education & & \\
\hline Nursing & 42 & 36.5 \\
\hline Social Sciences & 41 & 35.7 \\
\hline Human Services & 35 & 30.4 \\
\hline Behavioral Sciences & 29 & 25.2 \\
\hline Administration & 26 & 22.6 \\
\hline Psychology & 22 & 19.1 \\
\hline Nutrition / Dietetics & 22 & 19.1 \\
\hline Medicine & 19 & 16.5 \\
\hline Biology & 16 & 13.9 \\
\hline Epidemiology & 16 & 13.9 \\
\hline Business & 11 & 9.6 \\
\hline Occupational/Physical Therapy & 9 & 7.8 \\
\hline Physical Science & 9 & 7.8 \\
\hline Environmental Sciences & 7 & 6.1 \\
\hline Statistics & 6 & 5.2 \\
\hline Others & 6 & 5.2 \\
\hline None & 7 & 6.1 \\
\hline
\end{tabular}

Work Experience: The Work Experience job qualification was divided into four responsibility areas of Administration, Education, Research, and Other among the 115 job announcements (see Table 2). The most frequent Administration work experience required in descending order were Program Management \& Planning (66.1\%), Community Organization \& GroupOriented Work (60.9\%), Coordinating Health Education Services and Wellness Programs (59.1\%). Other Administration work experiences were required in less than half of the cases: Social Work, Human Services, Public Affairs (36.5\%), Fiscal, Grant or Health Market Management (32.2\%), Health Administration,
Supervision (25.2\%). The most frequent Education work experience required was Community Program Planning and Evaluation (69.6\%). Classroom teaching was required in only $27.8 \%$ of the cases. The most frequent Research work experience required was Program Planning \& Evaluation Research Methods (53\%) (see Table 9). Behavioral and Epidemiological Research Methods were required in less than $20 \%$ of the cases respectively. Other work experience required included Working with Diverse Populations (66.1\%), Working with Multicultural Populations (60\%), clinical experience (27\%), and Consulting (23.5\%). 
Table 2

Work Experience Required for Jobs $(\mathrm{N}=115)$

\begin{tabular}{|l|r|r|}
\hline \multicolumn{1}{|c|}{ Work Experience Required } & Freq. & \multicolumn{1}{|c|}{$\%$} \\
\hline Administration & & \\
\hline Program Management \& Planning & 76 & 66.1 \\
\hline Community Organization \& Group-Oriented Work & 70 & 60.9 \\
\hline $\begin{array}{l}\text { Coordinating Health Education Services } \\
\text { \& Wellness Programs }\end{array}$ & 68 & 59.1 \\
\hline Social Work, Human Services, Public Affairs & 42 & 36.5 \\
\hline Fiscal, Grant or Health Market Management & 37 & 32.2 \\
\hline Health Administration, Supervision & 29 & 25.2 \\
\hline Education & & \\
\hline Community Program Planning and Evaluation & 80 & 69.6 \\
\hline Classroom Teaching & 32 & 27.8 \\
\hline Research & & \\
\hline Program Planning \& Evaluation Research Methods & 61 & 53.0 \\
\hline Behavioral Research Methods & 22 & 19.1 \\
\hline Epidemiological Research Methods & 15 & 13.0 \\
\hline Other & & \\
\hline Working with Diverse Populations & 76 & 66.1 \\
\hline Working with Multicultural Populations & 69 & 60.0 \\
\hline Clinical (Nursing, Dietetics, Counseling, Medicine) & 31 & 27.0 \\
\hline Consulting & 27 & 23.5 \\
\hline
\end{tabular}

Years of Work Experience: Most job positions required at least one year of work experience in health education (84.3\%). $72.2 \%$ of employers required between one and five years of experience in the field: $0-1$ year $(\mathrm{N}=7$, $6.1 \%), 1-2$ years $(\mathrm{N}=27,23.5 \%), 2-3$ years $(\mathrm{N}=29,25.2 \%), 3-5$ years $(\mathrm{N}=27,23.5 \%),>5$ years $(\mathrm{N}=14,12.2 \%)$

Bilingual Language: $85.6 \%$ of the 250 job announcements did not specify whether bilingualism was being sought as a job qualification. However, $8.4 \%$ required bilingualism, and $6 \%$ bilingual preferred. Spanish was the predominant bilingual language required or preferred.

Work Behaviors: Work behaviors required of applicants were working independently (86.1\%), self-motivation (86.1\%), and other (17.4\%) $(\mathrm{N}=115)$. Other behaviors identified were creativity, sensitivity, flexibility, working well in groups, being compassionate, patience, and a capacity for working well with children. Many of the job announcements stipulated more than one work behavior.

\section{Job Description}

Research Question \#7, "What are the job descriptions of community health education jobs in the USA from May-December 1998?”, was answered qualitatively examined first for typical descriptions of community health education jobs. Then, the target population(s) and specialty areas of the community health jobs were quantitatively examined. Other job description information revealed in this study included full versus part time status and personality characteristics required. Of the 115 respondents, 97 employers provided full time job positions (84.3\%). Only $15.7 \%$ of the jobs were part time.

\section{Typical Job Descriptions}

Job descriptions outlining the responsibilities of the community health educator were included in the original job announcements $(\mathrm{N}=250)$. The job descriptions were either merged in the job 
announcements or listed in a separate part titled "job description”, “job duties," "general description of the position," and "essential responsibilities." The contents of the job descriptions included the target population of the community health educator, the health issues or health programs the job position involved, and any methods, skills and program strategies required of the position.

The following were the typical job descriptions found in the original job announcements $(\mathrm{N}=250)$ :

1. Plans, implements, and coordinates assigned health programs (e.g., tobacco control, family planning, AIDS education, child health, etc.).

2. Conducts community needs assessments for the purpose of health program planning.

3. Designs and delivers health education programs for specific groups such as human service providers, health care providers, and the general public.

4. Conducts outreach programs to meet goals and objectives of specific plans.

5. Provides extensive coordination and collaboration with area social service agencies serving target populations.

6. Operates a computer to enter, modify and review data; retrieve health information.

7. Designs and distributes appropriate health education materials such as pamphlets, flyers, and posters.

8. Designs appropriate heath education curriculums, conduct health presentation, education training and teaching.

9. Prepares and publishes newsletters of other educational materials for purposes of community education and promotion of community programs.

10. Prepares news releases and special features on assigned health topics.

11. Provides consultation, advice, networking and support services to county and community organizations as appropriate.

12. Assesses and counsels clients in areas such as diet, health promotion, and behavior change.

13. Provides case management for selected high-risk individuals.
14. Maintains up-to-date referral systems for a variety of programs.

15. Reviews various documentation and processes, forwards, or takes other action as appropriate.

16. Gathers information and statistical data; performs research and conducts studies; and disseminates educational information.

17. Develops and implements evaluation tools to measure and program effectiveness.

18. Prepares grant applications, comprehensive reports, and various correspondence to program operations and activities; provides recommendations to produce a more effective program.

Other responsibilities identified were:

1. Maintains departmental files and records.

2. Maintains inventory of department supplies; initiates requests for new or replacement materials.

3. Answers the telephone and provides information.

4. Responds to requests for information or assistance.

Target Population of the Community Health Education Job

Below is a list of target populations identified among the community health education jobs (see Table 3). Many of the job announcements contained multiple listings of target populations (e.g., infant/maternal and families). A large number of job descriptions identified an agespecific target population (e.g., infant/maternal, children, youth, teens/adolescents, adults, seniors), while others identified target populations according to their social roles (e.g., health professionals, families, women, minority/diverse background, students). The Other target populations combined hard-toclassify populations (e.g., patients in hospital or clinics, work site, farmers, and consumers).

\section{Community Health Education Specialty Areas}

Table 4 lists the specialty areas of the community health education jobs in descending order of frequency $(\mathrm{N}=115)$. Many of the job announcements had multiple listing of specialty 
areas. The five most frequently occurring community health education specialty areas were: General (47\%), HIV/AIDS/TB/STD (32.2\%), Tobacco Prevention (27.8\%), Diabetes (18.3\%), and Chronic Diseases (17.4\%). For other listings, see Table 4. Jobs specialty areas not listed in the table occurred in less than $1 \%$ of the cases. These specialty areas included vision, trauma prevention, worksite security, health policy, health information, health care marketing, and career consulting.

Table 3

Target Population of Community Health Education Services (N=115)

\begin{tabular}{|l|c|r|}
\hline \multicolumn{1}{|c|}{ Target Population } & Frequency & \multicolumn{1}{c|}{ Percent } \\
\hline Community (General) & 63 & 54.8 \\
\hline Adults & 42 & 36.5 \\
\hline Women & 35 & 30.4 \\
\hline Children & 33 & 28.7 \\
\hline Teens / Adolescents & 29 & 25.2 \\
\hline Health Professionals & 29 & 25.2 \\
\hline Families & 28 & 24.3 \\
\hline Minority / Diverse Background & 28 & 24.3 \\
\hline Youth & 24 & 20.9 \\
\hline Students & 22 & 19.1 \\
\hline Seniors & 18 & 15.7 \\
\hline Infant / Maternal & 15 & 13.0 \\
\hline Other & 14 & 12.2 \\
\hline
\end{tabular}

Table 4

Community Health Education Specialty Areas $(\mathrm{N}=115)$

\begin{tabular}{|l|c|r|}
\hline Community Health Education Specialty Areas & Frequency & Percent \\
\hline General & 54 & 47.0 \\
\hline HIV / AIDS / TB / STD & 37 & 32.2 \\
\hline Tobacco Prevention & 32 & 27.8 \\
\hline Diabetes & 21 & 18.3 \\
\hline Chronic Diseases & 20 & 17.4 \\
\hline Obesity / Nutrition & 20 & 17.4 \\
\hline Cardiovascular Diseases & 19 & 16.5 \\
\hline Teen Girl's Pregnancy & 19 & 16.5 \\
\hline Substance Abuse & 18 & 15.7 \\
\hline Risk Behavior Prevention & 18 & 15.7 \\
\hline Mental Health & 17 & 14.8 \\
\hline Stress Management & 17 & 14.8 \\
\hline Breast / Cervical Cancer & 16 & 13.9 \\
\hline Asthma & 16 & 13.9 \\
\hline Domestic \& Sexual Violence Prevention & 16 & 13.9 \\
\hline Alcohol Abuse & 14 & 12.2 \\
\hline Hypertension & 13 & 11.3 \\
\hline Immunization Program & 13 & 11.3 \\
\hline Infant Mortality Prevention & 12 & 10.4 \\
\hline
\end{tabular}




\begin{tabular}{|l|c|r|}
\hline Community Health Education Specialty Areas & Frequency & Percent \\
\hline Lung Cancer & 11 & 9.6 \\
\hline Other Cancers & 11 & 9.6 \\
\hline Tuberculosis & 10 & 8.7 \\
\hline Environment Health & 10 & 8.7 \\
\hline Family Planning & 6 & 5.2 \\
\hline Food Security & 5 & 4.3 \\
\hline Pre-Hospital Emergency Prevention & 5 & 4.3 \\
\hline Traffic Safety Program & 2 & 1.7 \\
\hline Other & 11 & 9.6 \\
\hline
\end{tabular}

\section{Computer and Other Special Skills}

Research Question \#8, "What are the special skills being requested for community health education jobs in the USA from MayDecember 1998?”, was answered through a descriptive examination of the computer and other special skills required for the community health education position. What were the skills which employers in health education expected from their employees? Of the 115 respondents, most required word processing skills $(\mathrm{N}=85$, or $73.9 \%)$ and e-mail and Internet skills $(\mathrm{N}=69$, or 60.0\%). Other important computer skills included knowledge of presentation $(\mathrm{N}=51$, $44.3 \%)$, database management $(\mathrm{N}=42,36.5 \%)$, statistics $(\mathrm{N}=40,34.8 \%)$, and spreadsheet ( $\mathrm{N}=35,30.4 \%)$ Just typing skills were insufficient for jobs in the contemporary health education field (8.7\%). Besides these, some respondents also mentioned other skills $(\mathrm{N}=7$, $6.5 \%$ including web page design, web maintenance, and computer literacy.

Aside from computing skills, other special skills were important. Communication skills $(\mathrm{N}=91$, $79.1 \%)$, program planning $(\mathrm{N}=85,73.9 \%)$, program implementation $(\mathrm{N}=84, \quad 73.0 \%)$, program evaluation $(\mathrm{N}=81,70.4 \%)$, teaching and training $(\mathrm{N}=77,67.0 \%)$ and program assessment ( $\mathrm{N}=58,50.4 \%)$ were the most sought after. Other skills including administration and organization ( $\mathrm{N}=42,36.5 \%)$, supervision and coordination ( $\mathrm{N}=41,35.7 \%)$, budgeting $(\mathrm{N}=30$, 26.1\%), consulting ( $\mathrm{N}=26,22.6 \%)$, grant writing $(\mathrm{N}=35,30.4 \%)$, research $(\mathrm{N}=33,28.7 \%)$, and Other $(\mathrm{N}=7,6.0 \%)$.

\section{Travel Requirements}

Travel was required in $59.1 \%$ of the jobs offered $(\mathrm{N}=115)$. In $11.3 \%$ of the jobs, community health educators were not required to travel whereas $24.3 \%$ may need to travel. Therefore, most of the jobs in community health education $(83.4 \%)$ require or may require the employee to travel. There were missing data on $5.2 \%$ of the cases.

\section{Employee Compensation}

Research Question \#9, "What compensation packages for community health education jobs in the USA from May-December 1998?,” was answered by describing the salaries and benefits of the community health education jobs.

\section{Salaries}

The salaries of community health education jobs were defined according to whether the job was part-time or full-time, the level of education, and the years of experience. Since the sample was small $(\mathrm{N}=115)$ and the salaries had a mildly skewed distribution, median scores were reported. The median salaries were $\$ 13.98$ per hour for part-time and $\$ 36,000$. per year for fulltime jobs.

Community health educator salaries varied according to the level of college education required for the position ( $\mathrm{N}=115)$ (see Table 5). Full-time community health educators with only a baccalaureate degree earned $\$ 31,000$. for fulltime work. There was approximately an $\$ 8,000$. differential between those jobs requiring only an AAS degree versus those requiring a BA/BS degree. Likewise, approximately a $\$ 9,000$. 
differential between BA/BS and MA/MS degrees. There was a large differential of $\$ 18,000$. between those jobs requiring an MA/MS versus MA/MS, PhD Preferred. Those jobs requiring a $\mathrm{PhD}$ for the position earned less than those requiring an MA/MS, PhD Preferred.

\section{Salary Differenced According to Years of Work Experience}

Working experience also affected the health educator's salaries. In the full time job positions of the survey (see Table 6), the tendency was for health educators with greater working experience was to earn higher salaries. Taking the standard deviation into consideration, there were no significant differences in average salaries between working experience in " $0-1$ year" and "none needed". And there were also no obvious differences between " $0-1$ year working experience" and "1-2 year working experience”.

Table 5

Salaries for Full-Time Employees with College Degrees (N=115)

\begin{tabular}{|l|r|r|}
\hline \multicolumn{1}{|c|}{ Degree Required } & Median Salary & Std. Deviation \\
\hline AAS (N=2) & $\$ 23,000$. & $\$ 5,700$. \\
\hline BA/BS (N=35) & $\$ 31,200$. & $\$ 7,100$. \\
\hline BA/BS, MA/MS preferred (N=20) & $\$ 38,000$. & $\$ 13,100$. \\
\hline MA/MS (N=28) & $\$ 40,000$. & $\$ 12,100$. \\
\hline MA/MS, Ph.D. preferred (N=7) & $\$ 58,000$. & $\$ 12,100$. \\
\hline Ph.D. (N=4) & $\$ 55,500$. & $\$ 6,200$. \\
\hline
\end{tabular}

Table 6

Salaries for Full Time Employees with Work Experience (N=115)

\begin{tabular}{|l|r|r|}
\hline \multicolumn{1}{|c|}{ Years Of Experience } & \multicolumn{1}{c|}{ Median } & \multicolumn{1}{c|}{ Std. Deviation } \\
\hline None Needed $(\mathrm{N}=7)$ & $\$ 36,000$. & $\$ 7,800$. \\
\hline 0-1 year $(\mathrm{N}=6)$ & $\$ 32,000$. & $\$ 8,100$. \\
\hline 1-2 years $(\mathrm{N}=20)$ & $\$ 30,000$. & $\$ 9,300$. \\
\hline 2-3 years $(\mathrm{N}=25)$ & $\$ 35,000$. & $\$ 12,500$. \\
\hline 3-5 years $(\mathrm{N}=25)$ & $\$ 40,000$. & $\$ 13,500$. \\
\hline$>5$ years $(\mathrm{N}=14)$ & $\$ 56,000$. & $\$ 10,600$. \\
\hline
\end{tabular}

\section{Benefits}

The benefits were divided into many kinds: insurance, leaves, vacation, and other benefits like pension, bonus, paid training, tuition reimbursement, merit pay, etc.

Medical, dental, life, vision, and disability insurance was available to employees. $87.8 \%$ and $79.1 \%$ employers provided both employees and their families with medical and dental insurance, respectively (see Table 7). Among them, 9.6\% provided only their employees with medical insurance benefits; and $8.7 \%$ provided only their employees with dental insurance. Almost half of the employers provided both their employees and their families with life insurance (58.3\%), vision insurance (50.4\%), and disability insurance (43.5\%).

Table 8 lists the various leave plans provided by employers. Eighty seven percent of employers provided sick leaves and $74.8 \%$ provided paid sick leaves. Only $13.0 \%$ employees were unavailable for their sick leaves. $76.5 \%$ and 
67.8\% employers provided maternal and paternal leaves, respectively. Nearly half of the leaves, however, were unpaid.

At least $73 \%$ employers provided their employees with paid vacation (Table 9). The length of paid vacation time varied. Most employers provided 2 weeks of paid vacation (40.9\%). However, $9.6 \%$ of employers provided no paid vacation time. Among the institutions in which paid vacation was provided, 97.6\% provided from 2 to 4 weeks.
In addition to paid vacations, two thirds of community health education jobs had pension plan benefits (67.8\%), while only little more than half had paid training (53\%), and tuition reimbursement/ remission (52.2\%) benefits. Other benefits such as merit pay (30.4\%) and annual bonuses (12.2\%) occurred less frequently.

Table 7

Employee Insurance and Availability of Family Plan (N=115)

\begin{tabular}{|l|c|c|c|c|c|c|}
\hline & \multicolumn{2}{|c|}{$\begin{array}{c}\text { Yes, Available to } \\
\text { Family }\end{array}$} & \multicolumn{2}{c|}{$\begin{array}{c}\text { Yes, Unavailable to } \\
\text { Family }\end{array}$} & \multicolumn{2}{c|}{ No Insurance } \\
\hline & Freq. & $\%$ & Freq. & $\%$ & Freq. & $\%$ \\
\hline Medical Insurance & 101 & 87.8 & 11 & 9.6 & 3 & 2.6 \\
\hline Dental Insurance & 91 & 79.1 & 10 & 8.7 & 14 & 12.2 \\
\hline Life Insurance & 67 & 58.3 & 28 & 24.3 & 20 & 17.4 \\
\hline Vision & 58 & 50.4 & 19 & 16.5 & 38 & 33.0 \\
\hline Disability Insurance & 50 & 43.5 & 33 & 28.7 & 32 & 27.8 \\
\hline
\end{tabular}

Table 8

Leave Types $(\mathrm{N}=115)$

\begin{tabular}{|l|c|c|c|c|c|c|}
\hline \multicolumn{1}{|c|}{ Leave Types } & \multicolumn{2}{c|}{ Paid Leaves } & \multicolumn{2}{c|}{ Unpaid Leaves } & \multicolumn{2}{c|}{ No Leaves } \\
\hline & Freq. & $\%$ & Freq. & $\%$ & Freq. & $\%$ \\
\hline Maternal Leave & 46 & 40.0 & 42 & 36.5 & 27 & 23.5 \\
\hline Paternal Leave & 38 & 33.0 & 40 & 34.8 & 37 & 32.2 \\
\hline Sick Leave & 86 & 74.8 & 14 & 12.2 & 15 & 13.0 \\
\hline
\end{tabular}

Table 9

Weeks of Paid Vacation ( $\mathrm{N}=115)$

\begin{tabular}{|l|c|r|}
\hline \multicolumn{1}{|c|}{ Weeks of Vacation } & Frequency & \multicolumn{1}{c|}{ Percent } \\
\hline None & 11 & 9.6 \\
\hline 1 week & 2 & 1.7 \\
\hline 2 weeks & 47 & 40.9 \\
\hline 3 weeks & 22 & 19.1 \\
\hline 4 weeks & 13 & 11.3 \\
\hline No response & 20 & 17.4 \\
\hline
\end{tabular}

\section{Discussion}

This was an exploratory, descriptive study of community health education jobs in the USA from May-December 1998. Discussion of the results of this study is organized along the nine research questions under investigation. 


\section{Where Community Health Education Jobs Are Found on the Internet}

While traditional job listing sources, such as newspaper classified advertisements and professional journals, are still popular for jobseeking, Internet sources are becoming more popular. Job announcements and a more expeditious job searching source in recent years. Not only does it provide most of the job opening list without geographic restriction, it is also acting as an effective means to review job descriptions, transmit your cover letter and resume, complete company application forms, submit writing samples, provide written responses to interview questions and even receive and accept job offers via e-mail.

For community health educators, there are many ways to find jobs through the Internet. The most likely methods to find community health education jobs are through health education job web sites, organizational and governmental job web sites, job search engines, and online newspaper classified listings (Tomita \& Taub 1999). The most effective method to find community health education jobs is to use specialized health education job web sites, such as Health Education Professional Resources (HEPR) Job Bank. Among the primary job sources, the results of this study have shown that almost half of the job listings in community health education were from CareerPath, an online newspaper classified listing. One-fifth of the job listings were from America's Job Bank. Only a few were from the other web sites. Those who master the electronic world of the Internet, and are knowledgeable about health education job web sites, will greatly enhance their success of finding the ideal job.

\section{Seasonal Distribution of Community Health Education Jobs}

The results of this study indicated that the community health education job announcements varied according to month. Most job openings were advertised in the Fall, peaking in October. It is very likely that there is another peak in the Spring (indicated by relatively high percentage in May). However, the Spring peak is somewhat speculative due to the limitation on the scope of our data collection time span.
This seasonality perhaps can be explained by the seasonality of general business activity in the states; most people may take vacation in the Summer and/or holiday seasons. It might be difficult to organize interviews while some of the key persons in an organization are not available. This seasonality also coincides with the school calendar of most educational institutions. Special business activities related to fiscal year end could be another factor contributing to the number of December job announcements.

\section{Geographic Distribution of Community Health Education Jobs}

The geographic distribution of the community health education job announcements varied according to region of the country. The differences are likely to be related to demographic and economic statuses of each region. There were more job announcements in the northeast and west, possibly due to dense populations and strong economic growth.

\section{Job Titles}

There were 143 job titles for Community Health Educator. The results of this study identified four categories of community health education job titles according to target health issue, job qualification, professional hierarchy, administrative hierarchy, or area of professional responsibility. It may be helpful for health education professional associations such as Society for Public Health Education (SOPHE, 2000), American Association for Health Education (AAHE, 2000), and International Union for Health Promotion and Education (IUHPE, 2000) to educate employers about what job titles are acceptable and what are the responsibilities of a community health educator. Education of employers is not a new idea. The New York State Coalition for Health Education (NYSCHE, 2000) has been a leading advocate for educating employers about the health education profession for many years, and their employers brochure have served as models for other professional associations to use (NYSCHE, 2000).

There are more pragmatic reasons for standardizing health education job titles. For 
example, job titles may affect the way in which health educators and students find jobs using the Internet. Using the keywords "health educator" may produce only those job titles containing those words. Other job titles such as Wellness Coordinator may be missed during the search.

\section{Work Environment Characteristics}

The study has shown that the majority of community health education jobs being offered were in non-profit and governmental institutions. Over half were from non-profit institutions alone (excluding governmental institutions). For profit organizations only provided insignificant amount of job openings in the same period.

Nine community health education work settings were classified in this study. Most of the jobs being offered were in governmental health departments and nonprofit health-related organizations. There were very few job openings in the clinical setting, educational institutions, for teaching and counseling students, and for-profit companies.

\section{Job Qualifications}

The discussion of Job Qualifications will parallel the results presented in the previous chapter. These job qualification areas include: college degree, licensure/certification, college major, type of work experience, and years of work experience.

College Degree and Licensure/Certification Job Qualification: As Pickett and Pickett (1995) found in their study that public health educators needed at least a bachelor's degree with a major in health science or community/public health education. There are many undergraduate programs in community health education that qualify the students for entry-level jobs. A master's degree in public health is a plus and often is required for posts above the entry level. If they wish to progress into program planning, design, and implementation, they need graduate training in an accredited program (Pickett \& Pickett, 1995).

The findings in this study support the conclusions by Pickett \& Pickett (1995). The majority of the jobs required at least bachelor's degree. There were very few community health education jobs that required only an AAS degree or no degree was required at all.

The role of the health educators are well recognized to be more than simply delivering health information (McKenzie \& Lurs, 1993). In order for those health educators who are responsible for planning, implementing, and evaluating health promotion and disease prevention programs to be successful in their work, they must have the requisite skills and knowledge. The Certified Health Education Specialist (CHES) (NCHEC, 2000) credential was designed to meet the goal of standardizing the minimum level of professional competence. However, the certification is not required in nearly all US states, although there are many benefits derived from the credentialing of school health educators (Girvan \& Kearns, 1993). This study also found that only small percentage of employers (8.4\%) required or preferred the community health educator applicant to possess the CHES certification. This implies that the benefits of CHES are not recognized by most employers. As discussed previously, more aggressive advocacy for the profession is needed by professional associations and the National Commission for Health Education Credentialing, Inc., to educate employers about what is a health educator, how are they professionally prepared, what are the benefits of hiring a health educator, and what is CHES.

College Major Job Qualification: The results of this study showed that most employers viewed majors other than health education to be acceptable professional preparation to perform the duties of a community health educator. Although almost $89 \%$ of employers required applicants to have a college major in health education or public/community health, they also listed other majors that would be acceptable, indicating that they did not understand the significance of hiring someone with the appropriate professional preparation. Apparently, health education is not view as a profession with a unique set of knowledge and skills if individuals with other college majors (e.g., biology, nutrition, psychology) are hired. 
These findings are consistent with previous studies. Alperin \& Miner (1993), for example, found that institutions often filled health education job positions with individuals who had diverse preparation rather than only applicants with a health education major. Perception by employers about the uniqueness of health education professional preparation may be one reason why other majors are considered acceptable for community health education jobs.

Work Experience Job Qualification: Work experience is one of the more frequently cited job qualifications employers seek in applicants (National Association of Colleges and Employers, 1999). In this study, work experience was divided into the four practice areas of administration, education, research, other. A common work experience across all practice areas was health education program planning and evaluation. Assessment, planning, implementation, and evaluation is at the heart of health education responsibilities and competencies. The community health educator is expected to manage health education programs, design curricula, and conduct research to determine whether the program has met its mission, goals, and objectives. All other responsibilities outlined above are related to one or more stages of the health education process. For example, community health educators were required to have had work experience with diverse and multicultural populations. Having such experiences gives the community health educator understanding of the culture for which the health education program is intended. Such understanding is essential to plan a program tailored specifically for that population.

It is unclear from this study what are the differences in definitions between "diverse population" and "multicultural population". These two terms may be synonymous? These terms should have been defined on the employer questionnaire. Diverse populations may have referred to the community health educator having to work with a wide range of individuals from different groups such as seniors, adolescents, gays, disabled, and so on. Multicultural populations may have referred to various racial and ethnic groups, most likely
African American and Hispanic. The significance of multiculturalism in training public health professionals and in implementing public health programs have received increasing attention in recent years (Bayer, 1994; Green, 1982; Orlandi, 1992). Cultural competency, or the ability to interact with multicultural people, is essential to the success of health educators. When culturally competent, health educators are sensitive to the values, norms and practices of target population, and adjust their patterns of interpersonal interaction accordingly: To demonstrate respect, not to give offense, and hence, to communicate more effectively. Cultural competence needs to be part of the basic qualifications of public health professionals in the modern world, and if it is not already, it should be a standard part of the curriculum of all schools of public health including health education (Buchanan, 1997-98).

Bilingual Language Job Qualification: As mentioned previously, many health educators worked in multicultural environments. In order to communicate with people with different cultural and language backgrounds, community health educators should have multicultural skills, understand different cultures, and communicate effectively with their target population in suitable languages. In the original 250 job announcements, $14.4 \%$ of the job required or preferred the respondents to be bilingual, primarily Spanish. This may be a trend, especially with the increasing Spanish population in the USA.

Work Behaviors Job Qualification: Work behavior appeared to be an important job qualification worth noting on job announcements. $86 \%$ of employers thought it was necessary to indicate they were looking for community health educators who could work independently and were self-motivated. Other work behaviors were identified. All of the behaviors listed may indicate that employers were defining professional behaviors: work independently, self-motivated, creative, sensitive, flexible, working well in groups or team players, compassionate, patient, capacity to work well with children. Are health education students taught in college what is professional 
behavior? Are health education students expected to conduct themselves professionally in preparation to becoming a community health educator?

\section{Typical Job Descriptions of Community Health Educators}

Job descriptions provide information about job situations and job environments. The content of job descriptions for community health education positions should include at least the following information: target population served by the community health educator, target health issues and programs, the methods to conduct the health education program and solve the health issues in order to acquire the purpose of health education, the role of community health educator in the program, and some special work environments.

Health educators work in diverse institutions, such as community organizations, schools, government agencies, hospitals, wellness centers, corporations, and so on. They must communicate with a variety of populations that might have corresponding health problems. In addition to general methods, skills, and program strategies which are suitable to all of the public, community health educators should recognize the specific characteristics of target individuals and groups: their behaviors, ethics, and psychology. Therefore, recognizing their targets served is the first step for health educators to pursue their purpose. It is also one of the important more important part of job announcements. Community health education job announcements should also include the community health education specialty areas, college degree and health education major, professional responsibilities and competencies required, computer and other special skills needed, travel requirements, and a broad listing of employee compensation that included a salary range.

\section{Employee Compensation}

Salaries: The median salary was almost \$14 per hour in part-time jobs, and $\$ 36,000$. per year in full-time jobs. When compared to the national averages, the salaries of community health educators are significantly lower (see Table 10). Such an apparent disparity in salaries in the health education profession when compared to national averages warrants further investigation.

Table 10

Comparison of Community Health Educator Salaries With National Income by Educational Attainment*

\begin{tabular}{|l|c|c|c|}
\hline \multicolumn{1}{|c|}{ College Degree } & $\begin{array}{c}\text { Community Health Educator } \\
\text { Median Income }\end{array}$ & \multicolumn{2}{c|}{$\begin{array}{c}\text { National Income } \\
\text { Median Income }\end{array}$} \\
\hline & & Male & Female \\
\hline & & & \\
\hline AAS & $\$ 23,000$ & $\$ 38,483$ & $\$ 28,377$ \\
\hline BA/BS & $\$ 31,200$ & $\$ 49,982$ & $\$ 35,408$ \\
\hline BA/BS, MA/MS preferred & $\$ 38,000$ & & \\
\hline MA/MS & $\$ 40,000$ & $\$ 60,168$ & $\$ 42,002$ \\
\hline MA/MS, Ph.D. preferred & $\$ 58,000$ & & \\
\hline Ph.D. & $\$ 55,500$ & $\$ 69,188$ & $\$ 52,167$ \\
\hline
\end{tabular}

* Source: U.S. Bureau of the Census

\section{Summary}

The purpose of this study was to explore the characteristics of community health education jobs in the USA from May-December 1998. Even though this study was based on 1998 data, the study provides valuable information to employers, health educators, and students about the status of community health education jobs. There is a need for a series of comprehensive national studies to be conducted to compare 
various health-related professions that includes health education. Such information may be useful to professional preparation programs and health educators to evaluate what needs to be done to further the profession's standing among other professions. The significant differences highlighted in this study regarding the median salaries between community health education jobs and USA national median incomes based on educational attainment should be a cause for alarm among health education professional leaders. Such disparities in salaries are unacceptable, and negatively impacts on professional preparation program recruitment.
Health education professional associations and the National Commission for Health Education Credentialing, Inc., may need to incorporate into their strategic plans with the highest priorities: 1) to educate employers about what is a health educator, what is an appropriate job title, what are acceptable job qualifications and job descriptions, and what compensation is appropriate; and 2) to enact measures that will elevate the standing of the profession among other health professions.

\section{References}

Alperin, M., \& Miner, K. R. (1993). Professional relevance: Meeting the contemporary public health agenda. Journal of Health Education, 24, 299-304.

American Association for Health Education. (2000). American association for health education. Retrieved December 14, 2000, from http://www.aahperd.org/aahe/aahe-main.html

AltaVista.com. (2000). ItaVista.com. Retrieved December 14, 2000, http://www.altavista.com/

America’s Job Bank. (2000). America’s Job Bank. Retrieved December 14, 2000, from http://www.ajb.dni.us/

Anonymous. (2000). Code of ethics for the health education profession. Journal of Health Education, 31, 216-218.

Anspaugh, D. J., Dignan, M. B., and Anspaugh, S. L. (2000). Developing health promotion programs. Boston: McGraw-Hill.

AnyWho. (2000). AnyWho. Retrieved December 14, 2000, from http://www.anywho.com/

Bajracharya, S. M. (1999). Employers’ perceived importance and use of skills that are specific to health educators: A replication study in a rural setting. The International Electronic Journal of Health Education, 1999, 2, 59-65.

Bartholomew, L. K., Parcel, C. S., Kok, G., Gottlieb, N. H. (2001). Intervention mapping: Designing theory- and evidence-based health promotion programs. Mountain View, CA: Mayfield Publishing.

Bayer. R. (1994). AIDS prevention and cultural sensitivity: Are they compatible? American Journal of Public Health, 84, 895-898.

BigBook. (2000). BigBook. Retrieved December 14, 2000, from http://www.bigbook.com/

Bonaguro, J. A.. \& Miaoulis, G. (1983). Marketing: A tool for health education planning. Health Education, 14, 6-11.

Breckon, J., Harvey, J. R., \& Lancaster, R. B. (1994). Community health education: Settings, roles, and skills for the 21st century. Gaithersburg, MD: Aspen Publishers.

Buchanan, D. R.(1997-98). Multiculturalism, racism and the training of public health professionals. International Quarterly of Community Health Education, 17, 213-219.

Butler, J. T. (1997). NCHEC and its responsibilities and competencies require reexamination. American Journal of Health Studies, 13, 169-173.

Capwell, E. M., Smith, B. J., Shirreffs, J., and Losen, L. K. (2000). Development of a unified code of ethics for the health education profession: A report of the national task force on ethics of health education. Journal of Health Education, 31, 212-214.

CareerPath. (2000). CareerPath. Retrieved December 14, 2000, from http://www.careerpath.com/

CareerWeb. (2000). CareerWeb. Retrieved December 14, 2000, from http://www.careerweb.com/ 
Chronicle of Higher Education. (2000). Chronicle of Higher Education. Retrieved December 14, 2000, from http://www.chronicle.com/

Cleary, H. (1995). The credentialing of health educators: An historical account 1970-1990. Allentown, PA: National Commission for Health Education Credentialing, Inc.

Cohen, J. (1988). Statistical power analysis for the behavioral sciences (2nd ed.). Hillsdale, NJ: Lawrence Erlbaum Associates.

Cottrell, R. R., Girvan, J. T., McKenzie, J. F. (1999). Principles \& foundations of health promotion and education. Boston: Allyn and Bacon.

Crase, D., \& Hamrick, M. H. (1990). The health education professorate: Demographics and projected retirements. Journal of Health Education, 21, 46-52.

Dillman, D. A. (2000). Mail and internet surveys: The tailored design method (2nd ed.). New York: John Wiley \& Sons, Inc.

DirectHit. (2000). DirectHi. Retrieved December 14, 2000, from http://www.directhit.com/

Doyle, E., \& Ward, S. (2001). The process of community health education and promotion. Mountain View, CA: Mayfield Publishing.

Eberst, R. (1984). Defining health: A multidimensional model. Journal of School Health, 54, 99-104.

Emory University. (2000). Public Health Employment Connection. Retrieved December 14, 2000, from http://www.cc.emory.edu/

Girvan, J. T., \& Kearns, R. L. (1993). The case for school health educators becoming certified health education specialists. Journal of Health Education, 24, 296-298.

Green, J. W. (1982). Cultural awareness in human services. Englewood Cliffs, NJ: Prentice-Hall.

Green, L. W., \& Kreuter, M. W. (1991). Health promotion planning: An educational and environmental approach (2nd ed). Mountain View, CA: Mayfield.

Hager, B. L. (1997). The professionalization of health educators in Arkansas: The health educator practice act. The CHES Bulletin Summer, 8, 2, 23.

Hayden, J. (1990). Preparing for certification: Health educators' perceived competencies. Journal of Health Education, 21, 41-42.

Health Education Directory. (2000). Health Education Directory. Retrieved December 14, 2000, from http://131.230.221.136/iejhe/

Health Promotion Recruiters International. (2000). Health Promotion Recruiters International. Retrieved December 14, 2000, from http://www.hpri.com/

HotBot. (2000). HotBot. Retrieved December 14, 2000, from http://www.hotbot.com/

International Union for Health Promotion and Education. (2000). International union for health promotion and education. Retrieved December 14, 2000, from http://www.iuhpe.org/

Jenkins, A. P. (1994). The health behaviors of health educators: A national survey. Journal of Health Education, 25, 324-331.

Joint Committee on Health Education Terminology. (1991). Report of the 1990 joint committee on health education terminology. Journal of Health Education, 22, 97-108.

Lindsay, G. A., Hanks, W. A., Neiger, B. L., and Barnes, M. D. (2000). Enhancing student employability: Perceptions of faculty advisors and community health practitioners. Journal of Health Education, 31, 10-15.

Linsky, A. S. (1975). Stimulating responses to mailed questionnaires: A review. Public Opinion Quarterly, 39, 82-101.

Mail, P. (1994). Quality assurance in health education. Journal of Health Education, 25, 333-37.

McKenzie, J. F., \& Lurs, J. L. (1993). Planning, implementing, and evaluating health promotion programs. New York: McMillan Publishing Company.

MonsterBoard. (2000). MonsterBoard. Retrieved December 14, 2000, from http://www.monster.com/

Moore, M. J., Pealer, L. N., Weiler, R. M., \& Seabert, D. M. (1999). A survey of search committee chairpersons: Candidate qualifications preferred for entry-level tenure-track health education faculty positions...including commentary by K. H. Beck. Journal of Health Education, 30, 297304. 
National Association of Colleges and Employers. (1999). National association of colleges and employers. Retrieved December 14, 2000, from http://www.naceweb.org/index2.cfm

National Commission for Health Education Credentialing, Inc.. (1996). A competency-based framework for professional development of certified health education specialists. Allentown, PA: Author.

National Commission for Health Education Credentialing, Inc.. (1999). A competency-based framework for graduate-level health educators. Allentown, PA: Author.

Netscape .(2000). Netscape. Retrieved December 14, 2000, from http://www.netscape.com/

New York State Coalition for Health Education. (2000). New York state coalition for health education. Retrieved December 14, 2000, from http://www.nyu.edu/education/hepr/nysche/

North Carolina Employment Security Commission. (2000). North Carolina employment security commission. Retrieved December 14, 2000, from http://www.esc.state.nc.us/

Orlandi, M. (1992). Cultural competence for evaluators. US Department of Health and Human Services, Public Health Service, Alcohol, Drug Abuse, and Mental Health Administration, Office for Substance Abuse Prevention, Rockville, MD. DHHS Publication, (ADM) 92-1884.

Parlette, N., Glogow, E., \& D’Lonofrio, C. (1981). Public health administration and health education need more integration. Health Education Quarterly, 8, 123-146.

Pickett, G. E., \& Pickett, T. W. (1995). Opportunities in public health careers. Chicago: NTC Publishing Group.

Ricketts, E. (2000). Tips for working in public health education. International Electronic Journal of Health Education, 3, 306-309.

SABPAC (1990). Manual on baccaulaureate health education program approval: Criteria and guidelines for self-study. Washington, D.C.: Society for Public Health Education (SOPHE) and Association for the Advancement of Health Education (AAHE) Baccalaureate Program Approval Committee.

SearchaLot. (2000). SearchaLot. Retrieved December 14, 2000, from http://searchalot.com/

SearchBug. (2000). SearchBug. Retrieved December 14, 2000, from http://www.searchbug.com/

Society for Public Health Education. (2000). Society for public health education. Retrieved December 14, 2000, from http://www.sophe.org/

Sondag, K. A., Taylor, E. L., \& Goldsmith, M. (1993). Employers’ perceptions of the importance of entry level health education skills. Journal of Health Education, 24, 305-310.

Squyres, W. (1982). The professional health educator in HMOs: Implications for training and our future in medical care. Health Education Quarterly, 9, 67-80.

Steuart G. W., \& Kark S. L. (1993). Community health education, principles and problems. Health Education Quarterly, Supplement 1, S29-S47.

Stoy, D. B. (2000). Developing intercultural competence: An action plan for health educators. Journal of Health Education, 31, 16-19.

Taub, A., \& Tomita, M. (2000). Health education professional resources. Retrieved December 14, 2000, from http://www.nyu.edu/education/hepr/

Timmreck,T. C., \& Cole, G. E. (1989). Health services administration skills: An overlooked need of community health education and health promotion. Health Education, 20, 36-44.

Tomita, M. (2000). Using the technology acceptance model to explain world wide web site use by health educators (Unpublished doctoral dissertation, New York University, 2000).

Tomita, M., \& Taub, A. (1999). Finding health education jobs on the Internet. Journal of Health Education, 30, 305-309.

U. S. Department of Labor. (2000). Occupational classification system manual. Retrieved December 14, 2000, from http://www.dol.gov/

U. S. Public Health Service. (1991). Healthy people 2000: National health promotion and disease prevention objectives. Washington, D. C.: GPO.

Yahoo!. (2000). Yahoo!. Retrieved December 14, 2000, from http://www.yahoo.com/

Weitzman, E. A. (1999). Analyzing qualitative data with computer software. Health Services Research 34, Part II, 1241-1251. 


\title{
Acknowledgements
}

This paper was a master's thesis submitted in partial fulfillment of the degree requirements for the MS in Computer Science and Health Science, Department of Health and Nutrition Sciences, Brooklyn College of the City University of New York, December 2000. Thesis award January 2001. Thesis Mentor: Mark Tomita, PhD, RN, CHES (mtomita@csuchico.edu).

I wish to express my deepest appreciation to Professor Mark Tomita for his valuable suggestions and selfless support!

Special thanks to my wonderful wife, Jun Gong. Thank you for all the years of love and support, especially during the period of my study in USA!

\author{
Author Information \\ Dr. La Wu, Research Associate \\ Angion Biomedica, Inc. \\ 350 Community Drive \\ Manhasset, NY 11030 \\ Ph. 516-562-1098 \\ E-Mail: wulajun@yahoo.com
}




\section{Appendix A \\ Health Education Employer Questionnaire \\ (Appendix A is available in RTF format)}

Instructions: Please complete ONLY the questions highlighted in YELLOW.

\section{INSTITUTION INFORMATION:}

1. Institution Kind 1 (Check ONLY one):

$\square$ Community Health Center

$\square$ Hospital, Clinics, Nursing Home, etc.

$\square$ Health Department (County, City, State, Nation)

$\square$ Health Research Institution (University, Government, Private, etc.)

$\square$ School, College, University

$\square$ Insurance Company

$\square$ Nonprofit health-related agency

$\square$ Business Health Consulting Organization

$\square$ Health Management Organization (HMO, POS, etc.)

$\square$ Others (Please specify):

2. Institution Kind 2 (Check ONLY one):
$\square$ Non-Profit
Profit
Government

3. Institution Kind 3 (Check ONLY one):
$\square$ Public
$\square$ Private

\section{JOB QUALIFICATIONS:}

4. Which Health Education major is needed (Check all that apply)?
$\square$ Health Education
$\square$ Public/Community Health
Other (Please specify):

5. Are there alternative majors acceptable for the job (Check ALL that apply)?
$\square$ Administration
$\square$ Behavior Science
$\square$ Biology
$\square$ Business
Education
$\square$ Environment science
Epidemiology
$\square$ Nutrition/Dietetics
Health Related Majors
Human Services
$\square$ Medicine
$\square$ Nursing
$\square$ Occupational / Physical Therapy
$\square$ Physical Science
$\square$ Psychology
$\square$ Statistics
$\square$ Social Sciences (Public Relation, Communication)
$\square$ Other (Please specify):

6. What degree is desirable for the Health Education job (Check ONLY one)?
$\square$ AAS
$\mathrm{BA} / \mathrm{BS}$
MA/MS, PhD Preferred
BA/BS, MA/MS preferred
$\square \mathrm{MA} / \mathrm{MS}$
No degree required
$\square \mathrm{PhD}$ Degree 
7. Years of health education experience needed for the job (Check ONLY one)?
$\square$ None
$\square 0-1$ year
$\square$ 1-2 years
$\square 2-3$ years
$\square$ 3-5 years
$\square>5$ years

8. What specific experiences are needed to do the job? (Check ALL that apply)?

\section{Administration:}

Health administration, supervision

Program management and planning in health education or wellness

Coordinating health education service, wellness program

Fiscal, grant or health market management

Community organization, and other group oriented work

Social work, human services, public affairs

ALL OF THE ABOVE

\section{Education:}

Community program planning and evaluation experience in a specific area of health education (e.g., drugs, tobacco, alcohol, childbirth, sexuality, family planning, domestic violence, etc.) Classroom teaching

ALL OF THE ABOVE

\section{Research:}

Behavioral research methods

Program planning and evaluation research methods

Epidemiological research methods

\section{ALL OF THE ABOVE}

\section{Other Experiences:}

Clinical (e.g., professional nursing, dietetics, social work, counseling, medicine)

Working with multicultural populations (e.g., African, Native, Hispanic Americans, etc.)

Working with diverse populations (adolescents, students, seniors, gay men, low income families, etc.)

Consulting

ALL OF THE ABOVE 
9. Years of experience needed in these fields (Check ONLY One)?
$\square$ None
$\square 0-1$ year
$\square 1-2$ years
$\square 2-3$ years
$\square$ 3-5 years
$\square>5$ year

\section{JOB DESCRIPTION:}

10. The health educator will be mainly serving which population (Check ALL that apply)?
$\square$ Adult
$\square$ Children
$\square$ Minority
$\square$ Community (General)
$\square$ Seniors
$\square$ Family
$\square$ Students
$\square$ Health Professionals
$\square$ Teens /Adolescents
$\square$ Infant/Maternal
$\square$ Women
$\square$ Other (Please specify):
$\square$ Youth

11. In what health education area will the health educator focus (Check ALL that apply)?
$\square$ Alcohol Abuse
Asthma
$\square$ Breast / Cervical Cancer
$\square$ Cardiovascular Diseases
$\square$ Chronic Diseases
$\square$ Diabetes
$\square$ Domestic \& Sexual Violence
$\square$ Environment Health
$\square$ Food Security
$\square$ General
$\square$ Hypertension
Immunization
Infant Mortality Prevention
Lung Cancer

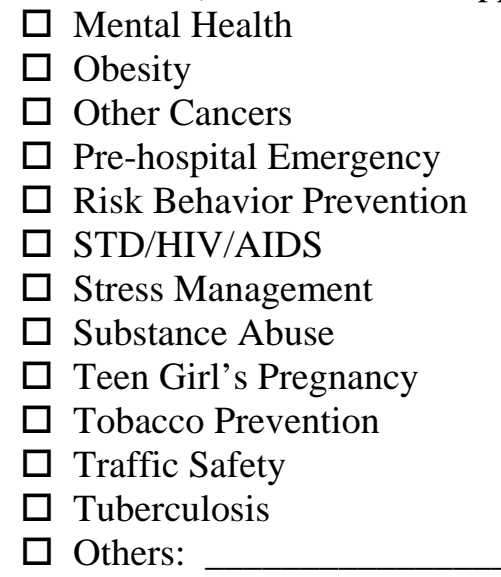

12. Which computer skill(s) is/are needed for the job (Check ALL that apply)?
$\square$ Word Processing
$\square$ Presentation
Database Management
$\square$ Spreadsheet
$\square$ Statistics
E-mail and Internet
$\square$ Just Typing
$\square$ Other:

13. Are any following special skills needed for the job (Check ALL that apply)?
$\square$ Administration
$\square$ Budgeting
$\square$ Communication
$\square$ Consulting
$\square$ Grant Writing
$\square$ Program Planning
$\square$ Program Implementation
$\square$ Program Evaluation
$\square$ Program Assessment
$\square$ Research
$\square$ Statistics
$\square$ Supervision
$\square$ Teaching/Training
$\square$ Other (Please specify): 
14. What personalities is needed for the job (Check ALL that apply)?

$\square$ Self-motive $\square$ Work Independently $\square$ Others:

15. Is there any travel needed for the job (Check Only One)?
$\square$ Yes
No
$\square$ Maybe

\section{BENEFITS:}

16. Average annual salary of the health education job offered?

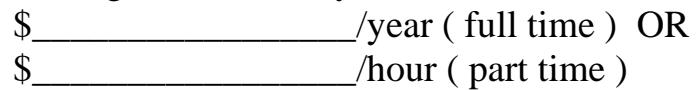

17. What benefits are provided to your employee? (Check ALL that apply)

Employee Insurance:

Medical Insurance

Dental Insurance

Life Insurance

Disability Insurance

Vision
Family Plan Available:

$\begin{array}{ll}\square \text { Yes } & \square \text { No } \\ \square \text { Yes } & \square \text { No } \\ \square \text { Yes } & \square \text { No } \\ \square \text { Yes } & \square \text { No } \\ \square \text { Yes } & \square \text { No }\end{array}$

Leaves:

$\square$ Maternal Leave
$\square$ Paternal Leave
$\square$ Sick Leave

Paid Leave?

$\begin{array}{ll}\square \text { Yes } & \square \text { No } \\ \square \text { Yes } & \square \text { No } \\ \square \text { Yes } & \square \text { No }\end{array}$

Other Benefits:

Pension

Annual Bonus

Paid Training
Tuition Reimbursement / Remission

$\square$ Merit Pay

Paid Vacation:

$\square$ None

1 week

2 weeks

3 weeks

$\square 4$ weeks

$\square$ Other

Person completing this questionnaire:

$\square$ Supervisor, Administrator

$\square$ Administration Assistant / Secretary

Health educator

Other

THANK YOU VERY MUCH FOR YOUR ASSISTANCE! 


\section{Appendix B}

Complete List of Job Titles

\begin{tabular}{|c|c|c|c|}
\hline \multicolumn{2}{|r|}{ Job Title } & Frequency & Percent \\
\hline 1. & Abstinence Education Outreach Worker & 1 & .4 \\
\hline 2. & Abstinence Education Program Coordinator & 1 & .4 \\
\hline 3. & AIDS Education Coordinator & 1 & .4 \\
\hline 4. & AIDS Educator & 1 & .4 \\
\hline 5. & Assistant Health Planner & 1 & .4 \\
\hline 6. & Assistant Wellness Director & 1 & .4 \\
\hline 7. & Associate Project Director & 1 & .4 \\
\hline 8. & Behavior Change Manager & 1 & .4 \\
\hline 9. & Bilingual Family Educator & 1 & .4 \\
\hline 10. & Breast Wellness Program Manager & 1 & .4 \\
\hline 11. & Cancer Information Specialist & 1 & .4 \\
\hline 12. & Certified Childbirth Educator & 1 & .4 \\
\hline 13. & Communications Coordinator & 1 & .4 \\
\hline 14. & Community Affairs Specialist & 1 & .4 \\
\hline 15. & Community Education Coordinator & 1 & .4 \\
\hline 16. & Community Educator & 1 & .4 \\
\hline 17. & Community Health Education Coordinator & 1 & .4 \\
\hline 18. & Community Health Educator & 2 & .8 \\
\hline 19. & Community Health Educator II & 1 & .4 \\
\hline 20. & Community Health Manager & 1 & .4 \\
\hline 21. & Community Health Specialist & 2 & .8 \\
\hline 22. & Community Service/Health Educator & 1 & .4 \\
\hline 23. & Community Wellness Specialist & 1 & .4 \\
\hline 24. & Consultant, Public Health Nurse & 1 & .4 \\
\hline 25. & Coordinator of School Health Training Center & 1 & .4 \\
\hline 26. & $\begin{array}{l}\text { Coordinator, Patient \& Community Health } \\
\text { Education }\end{array}$ & 1 & .4 \\
\hline 27. & Coordinator, Public Health Education & 1 & .4 \\
\hline 28. & Coordinator, School Health \& Wellness Center & 1 & .4 \\
\hline 29. & Corporate Wellness Manager & 1 & .4 \\
\hline 30. & CPR and First Aid Instructor & 1 & .4 \\
\hline 31. & Dean of Health Careers and Wellness & 1 & .4 \\
\hline 32. & Diabetes Project Coordinator & 1 & .4 \\
\hline 33. & Director & 3 & 1.2 \\
\hline 34. & Director of Community Services & 1 & .4 \\
\hline 35. & Director of Health Promotion & 1 & .4 \\
\hline 36. & Director, Community Health and Education & 1 & .4 \\
\hline 37. & Director, Health Education \& Wellness & 1 & .4 \\
\hline 38. & Director, Office of Prevention & 1 & .4 \\
\hline 39. & Disease Control Program Administrator & 1 & .4 \\
\hline 40. & Disease Intervention Specialist & 1 & .4 \\
\hline & Educational Coordinator & 1 & .4 \\
\hline 42. & Executive Director & 3 & 1.2 \\
\hline & Health and Physical Education & 1 & .4 \\
\hline
\end{tabular}




\begin{tabular}{|c|c|c|}
\hline Job Title & Frequency & Percent \\
\hline Health and Wellness Coordinator & 1 & .4 \\
\hline Health care program manager & 1 & .4 \\
\hline Health Counselor & 1 & .4 \\
\hline Health Editor & 1 & .4 \\
\hline 48. $\quad$ Health Education \& Patient Outreach & 1 & .4 \\
\hline Health Education \& Wellness Manager & 2 & .8 \\
\hline Health Education Assistant & 1 & .4 \\
\hline Health Education Associate & 2 & .8 \\
\hline Health Education Coordinator & 1 & .4 \\
\hline 53. $\quad$ Health Education GEN & 1 & .4 \\
\hline 54. $\quad$ Health Education Program Coordinator & 1 & .4 \\
\hline 55. Health Education Program Manager & 1 & .4 \\
\hline 56. $\quad$ Health Education Project Specialist & 1 & .4 \\
\hline 57. Health Education Research \& Training Coordinator & 1 & .4 \\
\hline 58. $\quad$ Health Education Service Coordinator & 1 & .4 \\
\hline 59. $\quad$ Health Education Specialist & 7 & 2.8 \\
\hline 60. $\quad$ Health Education Specialist II & 2 & .8 \\
\hline 61. $\quad$ Health Educator & 64 & 25.5 \\
\hline 62. $\quad$ Health Educator Aide & 1 & .4 \\
\hline 63. Health Educator Assistant & 3 & 1.2 \\
\hline 64. $\quad$ Health Educator II & 6 & 2.4 \\
\hline 65. $\quad$ Health Educator III & 1 & .4 \\
\hline 66. Health Educator Specialist & 1 & .4 \\
\hline 67. Health Educator, Childbirth & 1 & .4 \\
\hline 68. Health Educator, Community Development & 2 & .8 \\
\hline 69. Health Educator, OB/GYN & 2 & .8 \\
\hline Health Educator, Project Manager & 1 & .4 \\
\hline 71. Health Educator/Coordinator of Special Programs & 1 & .4 \\
\hline 72. $\quad$ Health Educator/Counselor & 2 & .8 \\
\hline 73. $\quad$ Health Information Specialist & 2 & .8 \\
\hline 74. $\quad$ Health Officer & 1 & .4 \\
\hline 75. $\quad$ Health Program Manager & 2 & .8 \\
\hline 76. $\quad$ Health Program Specialist 1 & 1 & .4 \\
\hline 77. Health Promoter & 1 & .4 \\
\hline 78. $\quad$ Health Promotion Director & 1 & .4 \\
\hline 79. $\quad$ Health Promotion Manager & 1 & .4 \\
\hline 80. $\quad$ Health Promotion Quality Standards Coordinator & 1 & .4 \\
\hline 81. $\quad$ Health Promotion Supervisor & 1 & .4 \\
\hline 82. $\quad$ Health Teacher & 1 & .4 \\
\hline 83. Healthcare Research Specialists & 1 & .4 \\
\hline 84. $\quad$ HIV Health Educator & 1 & .4 \\
\hline 85. $\quad$ HIV/AIDS Educator & 1 & .4 \\
\hline 86. HIV/AIDS Health Educator & 3 & 1.2 \\
\hline 87. $\quad$ Lifestyle Educator II & 1 & .4 \\
\hline 88. Peer Health Education Program Coordinator & 1 & .4 \\
\hline 89. Prenatal Case Manager, Health Educator II & 1 & .4 \\
\hline 90. $\quad$ Professional Development Director & 1 & .4 \\
\hline 91. $\quad$ Program Coordinator & 1 & .4 \\
\hline
\end{tabular}




\begin{tabular}{|c|c|c|}
\hline Job Title & Frequency & Percent \\
\hline Program Coordinator, Health Careers Promotion & 1 & .4 \\
\hline Program Coordinator, Professional Development & 1 & .4 \\
\hline Program Development Specialist & 1 & .4 \\
\hline Program Director & 1 & .4 \\
\hline Program Manager & 2 & .8 \\
\hline Program Specialist III & 1 & .4 \\
\hline 98. $\quad$ Project Coordinator & 3 & 1.2 \\
\hline 99. $\quad$ Project Coordinator, Foundation & 1 & .4 \\
\hline 100. Project Director & 3 & 1.2 \\
\hline 101. Project Manager & 5 & 2.0 \\
\hline 102. Project Specialist & 1 & .4 \\
\hline 103. Public Affairs Associate & 1 & .4 \\
\hline 104. Public Health Advisor & 2 & .8 \\
\hline 105. Public Health Assistant Director & 1 & .4 \\
\hline 106. Public Health Educator & 6 & 2.4 \\
\hline 107. Public Health Educator II & 4 & 1.6 \\
\hline 108. Public Health Educator III & 1 & .4 \\
\hline 109. Public Health Promotion Regional Coordinator & 1 & .4 \\
\hline 110. Public Health Representative III & 1 & .4 \\
\hline 111. Regional Coordinator & 1 & .4 \\
\hline 112. Research Assistant & 3 & 1.2 \\
\hline 113. Research Associate & 1 & .4 \\
\hline 114. Research Coordinator & 1 & .4 \\
\hline 115. $\quad$ Research Data Analyst & 1 & .4 \\
\hline 116. Research Fellow/Associate & 1 & .4 \\
\hline 117. Research Manager & 1 & .4 \\
\hline 118. $\quad$ Research Scientist, Level II & 1 & .4 \\
\hline 119. $\quad$ Research Scientist, Level III & 1 & .4 \\
\hline 120. Research Specialist & 1 & .4 \\
\hline 121. Sanitarian & 1 & .4 \\
\hline 122. Senior Clinical Quality Specialist & 1 & .4 \\
\hline 123. Senior Evaluator / Researcher & 1 & .4 \\
\hline 124. Senior Health Educator & 1 & .4 \\
\hline 125. Senior Health Program Planner & 1 & .4 \\
\hline 126. $\quad$ Senior Health Promotion Specialist & 1 & .4 \\
\hline 127. Senior Training Manager & 1 & .4 \\
\hline 128. Services Coordinator & 1 & .4 \\
\hline 129. Social Work Associate & 1 & .4 \\
\hline 130. Supervisory Health Scientist & 1 & .4 \\
\hline 131. Teen Reproductive, Health Educator & 1 & .4 \\
\hline 132. Well Aware Program Coordinator & 1 & .4 \\
\hline 133. Wellness Education Consultant & 1 & .4 \\
\hline 134. Wellness Outreach Coordinator & 1 & .4 \\
\hline 135. Wellness Program Manager & 1 & .4 \\
\hline 136. Wellness Technician & 2 & .8 \\
\hline 137. Working Well Manager & 1 & .4 \\
\hline Total & 250 & 100.0 \\
\hline
\end{tabular}

